\title{
Models of Authoritarian Regimes: A Critique*
}

\author{
Adam Przeworski \\ Department of Politics \\ New York University
}

\begin{abstract}
The very idea that authoritarian regimes ("autocracies") may enjoy popular support is hard to fathom for democrats. Models of authoritarian regimes often entail tacit ideological assumptions and many are driven by methodological fashions. They fail to elucidate complex psychological mechanisms that shape people's postures toward these regimes. "Support" for any regime is difficult to asses.
\end{abstract}

\section{Introduction}

We now have a canonical view of authoritarian regimes. A dictator (autocrat), individual or collective, maximizes the probability of survival in office or the expected rents, using instruments that include cooptation, repression, censorship, propaganda, and the like. These instruments differ in their effectiveness and their costs. In the (Stackelberg) equilibrium, the dictator chooses their optimal mix subject to some constraints. Comparative statics depend on the exogenously given cost and effectiveness parameters. (Guriev and Treisman 2015 is the best summary of this view.)

This view is based on assumptions that are laden with ideological biases and are often driven by methodological fashions. The ideology is flagrant even at a purely semantic level. Game-theoretic articles on "persuasion" (Kamenica and Gentzkow 2011, Galperti 2018) use this concept in purely neutral terms. Yet when such models are applied to authoritarian regimes "persuasion" becomes "manipulation" (Chan and

*An earlier version suffered from comments by James Fearon, Stephen Holmes, Andrew Little, Zhaotian Luo, Bernard Manin, Arturas Rozenas, Ignacio SanchezCuenca, Mehdi Shadmehr, Milan Svolik, and Tiberiu Dragu. 
Suen 2008, Edmond 2013, Gelbach and Simpser 2015, Rozenas 2016), in the same way as "information" becomes "propaganda" (Little 2017), without any difference in the structure of the models. But the ideological roots are much deeper. The very idea that autocracies may enjoy popular support is hard to fathom for democrats. Unless they are "brainwashed" or "indoctrinated," how can people conceivably support an autocrat?

Autocracies are assumed to be inherently brittle, surviving only because people are misled or repressed. This focus on regime survival diverts our attention away from their routine functioning. Certainly, in the end all actions by government officials have some effects of regime stability. But this does not mean that all their actions are motivated by the concern for surviving in power. Autocracies do collect garbage, regulate traffic, issue dog licenses, fill street holes, vaccinate children, have cops break street fights: they govern. In turn, the individuals who populate these models are assumed to have postures toward the regimes - for or against - at every moment of their lives. But ordinary people are not politically hyperactive in any regime. People in autocracies do not incessantly live under the shadow of dramatic historical events; they lead everyday, routine, lives. Political crises that engage popular involvement are special moments. As Pepinsky (2017) incisively observed, "Life in authoritarian states is mostly boring and tolerable."

Game-theoretic models of authoritarianism assume that most people are rational, even if not completely informed, that everyone has "beliefs" and acts according to them, and individuals either "support" the regime or act against it. My dissatisfaction with these assumptions has personal roots: they just do not "feel right" for someone who actually lived under such regimes. Moreover, it is fed by ethnographic studies, such as Wedeen's (1999) work on Syria on which I rely extensively below, as well as personal accounts and novels, often more telling than models. I know that what does not feel right for some may be persuasive for others but the list of questions which this view leaves open is long and some of the puzzles are deep.

Mussolini claimed in retrospect that "Strictly speaking, I was not even a dictator, because my power to command coincided perfectly with the will to obey of the Italian people" (A note written to an Italian journalist, Ivanoe Fossani, in March 1945, quoted in Cassese 2011). Clearly, one can easily reject his claim as an ex-post excuse for repression. But is it true that Italian people did not want to follow Mussolini? Is the popularity of Messrs. Putin or Xi due only to their use of nasty, nondemocratic, instruments? (See Frye et al. 2015 on Russia, Chu 2011 on China.) Are postures toward autocratic regimes consistent with beliefs? What does it mean to "believe"? Are people duplicitous when they col- 
laborate with authoritarian regimes? Can we tell what is rational to do under different choice sets? And, in the end, what does it mean to "support" any regime?

As these questions make clear, some of them cannot be answered by using game-theoretic apparatus and perhaps some cannot be answered at all. But I hope to persuade others that if we are to understand how authoritarian regimes function, we need to drop both our ideological and methodological blinders. In what follows, I first briefly lay out the ideological assumptions shared by most models of authoritarian regimes. Then I delve into issues that I find puzzling.

\section{Assumptions}

\subsection{Rule of a minority?}

I myself blithely wrote some years ago that "dictators are dictators because they cannot win elections, because their preferences diverge from those of the majority of the population." (Gandhi and Przeworski 2006: 2). I am now eating these words because there certainly must have been at least some periods in the histories of some autocracies when they enjoyed widespread popular support.

Schumpeter (2010 [1942]: 221), who was never swayed by ideologies, observed that "Instances abound - perhaps they are the majority of historical cases - of autocracies, both dei gratio and dictatorial, of the various monarchies of non-autocratic type, of aristocratic and pluralistic oligarchies, which normally commanded the unquestioned, often fervent, allegiance of an overwhelming majority of all classes of their people...." The authority of the rulers in such regimes did not originate from their capacity to persuade but from their pre-assigned place. ${ }^{1}$ During the twentieth century such autocracies were replaced by revolutionary regimes that portrayed themselves as foundational, proclaiming that they would last forever, that they are a civilizational alternative to democracy: communism, fascism, "socialism with Chinese characteristics." At least during some period, these regimes probably enjoyed popular support. ${ }^{2}$ Yet even such autocracies are almost extinct by now.

\footnotetext{
${ }^{1}$ Whether authority results from places occupied in some hierarchy, such as the father in a family, or from being able to persuade has been a subject of controversy between Arendt (1954), who held the first position, and Friedrich (1958) who advocated the second.

${ }^{2}$ Stalin concluded by 1936 that the power of the supporters of the Tsarist regime and of the kulaks had been destroyed and actually made a move toward competitive elections but had to give up in the face of rebellion by middle-level party cadres (Getty 1991).
} 
Modern autocrats claim that they rule not only on behalf but also on bequest of "the people." What is new is that to validate this claim, modern autocrats hold elections, elections which they win.

We know from empirical research (Cox 2008, Geddes 2009, Przeworski 2015) that political leaders who hold elections of any kind, even those without opposition, have a longer expected tenure in office than those who do not. But reading popular support from results of controlled elections is tricky. ${ }^{3}$ When communists produced $99 \%$ turnout in single-list elections, they were just showing off their grip over the societies they ruled: such elections informed everyone about their coercive capacity but not about their support. But when elections admit some opposition, separating the weights of coercion, manipulation, and authentic support is not obvious (Little 2012, Luo and Rozenas 2018). In the end, just assuming that autocrats cannot enjoy popular support is pure ideology but interpreting results of elections is difficult.

\subsection{Everyone hates repression?}

Is it possible that masses of people would support violent repression? They did during the Stalinist purges of the 1930s (Goldman 2007), during the Cultural Revolution in China (Walder and Lu 2017), during the anti-Semitic campaign in Poland in 1968.

The standard view is that repression is used by autocrats to deter opposition and probably most of the time it is used for this purpose. I wonder whether individually targeted repression is what matters most. Repression is something more general: deeply internalized fear, widespread perception that the regime will survive no matter what, that all resistance is futile.

In turn, repression used against particular groups rather than against individuals who are suspected to hold anti-regime postures may well be supported by other groups. As Rozenas (2020: 2) observes, "A group that is supportive of the regime becomes an even stronger supporter when the other group is repressed, because it infers that the repressed group will be deterred as it does not expect the supportive group to reciprocate in opposing the regime." For Rozenas, the autocrat thus uses repression to prevent coordination among potential opponents. Yet the use of group-targeted repression may just cater to crass prejudices, anti-Semitic in Nazi Germany or Communist Poland, anti-Muslim in contemporary Myanmar, anti-Indian in El Salvador. When societies are antagonistically divided along some ethnic or religious lines, grouptargeted repression feeds the prejudices of a majority and increases the

\footnotetext{
${ }^{3}$ On this topic, I have learned a lot from Arturas Rozenas.
} 
support for the regime. Strictly distributive considerations may also play a role: restricting access of Jews to some professions was welcomed by non-Jewish majorities in Nazi Germany as well as pre-war Poland because it opened access to them. The waves of repression in Stalin's Russia and Mao's China were unleashed to protect the leaders from the ire of the masses by scapegoating the "bureaucrats" and it appears that their repression was supported by many workers and peasants. ${ }^{4}$

\subsection{Bases of support}

An opening sentence of a recent paper summarizes in a nutshell, "How do autocrats govern? Roughly speaking, the literature has identified two broad sets of strategies that autocrats use to hang onto power and pursue policy goals: they can manipulate information, through censorship and propaganda, and they can repress" (Gehlbach et al. 2021). Authoritarian rulers build their support by using repression and manipulating information. Does it make no difference whether they deliver material and symbolic goods most people value? Is it irrelevant that the average Chinese incomes increased sixfold since 1978? That Russians value restoration of order provided by Putin? ${ }^{5}$ That both Chinese and Russians find pride in nationalist adventures? ${ }^{6}$

Most models analyze sub-games in which the distribution of the states of the world is taken as given. If the state of the world happens to be good, the autocrat does nothing. If it happens to be bad, he censors information, explains away the bad news that filter through the censorship by propaganda, and if both censorship and propaganda fail, activates repression. So the autocrats do nothing to make states of the world more likely to be good: they do not promote growth, pay attention to income inequality, build armies, invest in the performance of sport teams in international competitions, ..., nothing that people may care about.

Guriev and Treisman (2019) document the evolution of autocracies from relying on brute force to relying on manipulating information. But I find it striking that they never consider actual performance, only infor-

\footnotetext{
${ }^{4}$ The irrationality of this support is wonderfully captured by Victor Serge's, The Case of Comrade Tulayev: the vice-Director conspires to have the Director sent to Siberia, so as to become Director, whose vice-Director conspires, and so it goes.

${ }^{5}$ Using a series of public opinion data, Matovski (2018) argues that Russians care above everything else about stability and order, which is provided by strong-armed leadership, and they are averse to any alternatives that may be destabilizing.

${ }^{6}$ Green and Robertson (2020: 3) report that the surge of emotional engagement in Russia after the annexation of Crimea "did much more than boost the furtuntes of the regime: it transformed the way Russians saw their lives, their futures and even their past, creating a wave of positivity."
} 
mation about performance. Yet even very crude facts are telling. Here is a regression of the probability of breakdowns of authoritarian regimes as a function of two lags of growth rates:

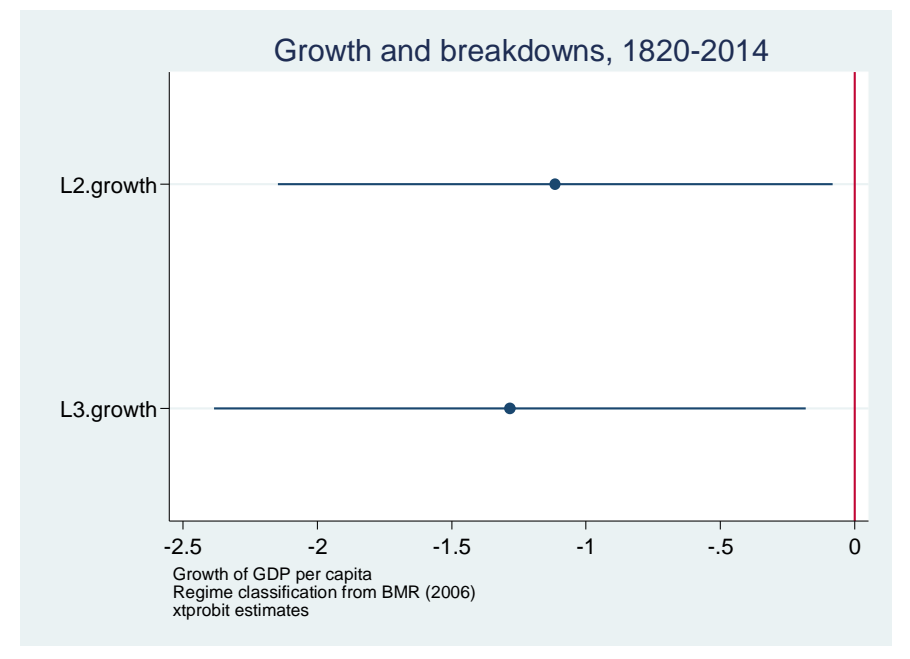

Performance informs by itself: the poor peasants of Chongqing who now live in nicely kept city apartments with incomes that doubled every five years do not need to be informed that they are better off. Smart autocrats may use performance to convey information (see Voiglandler 2019 on Hitler's autobahns) but it is because performance speaks for itself. Bayesian models of persuasion are intellectually attractive but it stretches imagination to think that the support for the Chinese Communist Party is due to its manipulation of information. ${ }^{7}$

The preoccupation with repression, censorship, and propaganda as props that maintain the regimes implicitly assumes that performance - delivery of whatever people want - is insufficient for an autocrat to survive. Suppose it is not. The empirical question is whether the application of such instruments can be ever sufficient if things are truly bad. I suspect that given what people experience in everyday lives, information manipulation is at most a fig leaf when things go badly and a sweetener when they go well. At least I know of no evidence that information manipulation has saved autocrats that would have otherwise fallen.

\subsection{How autocracies fall?}

Various counts of breakdowns of authoritarian regimes show that about $1 / 8$ of them occur as a consequences of mass protests, "from below"

\footnotetext{
${ }^{7}$ For a blood-curdling allegory of the Chinese regime see the story "Gubaiku spirit" in Chen (2020).
} 
(Svolik 2012) Yet the fashion of global games (Edmond 2013, Shadmehr and Bernhardt 2011) seems irresistible: most of the recent literature models mass protests.

The dichotomous distinction of "from below" and "from above" (divisions within the elite resulting in coups) may be too sharp. In many breakdowns of authoritarian regimes information about divisions within the elite incited popular mobilization while popular mobilization generated divisions within the elite (Przeworski 1991). When the authoritarian elite is confronted with mass protests, it divides about the strategy of coping with them: "hardliners" want to repress, "reformers" want to compromise because the support of a moderate opposition would increase their power within the authoritarian ruling bloc. When the opposition learns about the divisions within the elite, it senses that it has allies among the "reformers," so it mobilizes. Static equilibria of this such situations have been studied by Casper and Tyson (2014) but to my best knowledge their dynamics have not been analyzed.

Models of regime transitions fall in two distinct categories: some pay attention to the fundamentals but not to the events that generate transitions, other focus on the events without analyzing the fundamentals. Reading regime transitions just from comparisons of welfare of some representative agents under alternative regimes, as in a long line of models that follow Acemoglu and Robinson (2006), is clearly too mechanical in that it does allow for short-term dynamics. In turn, focusing on popular protests or divisions within the elite while taking the conditions as exogenous has little predictive power. Economic crises divide the elites because they pose the choice whether to ride them out by increasing repression or by seeking accommodation with some groups of the opposition, yet the outcome of such crises depends on success or failure of the strategies pursued by the actors involved. No models I know capture both.

Authoritarian regimes do fall but such events are rare in comparison to instances in which one autocrat replaces another. Sometimes such replacements result from coups within the ruling elite, as when General Viola removed General Videla, sometimes one autocratic regime is replaced by another, as when the Mullahs succeeded the Shah. Autocrats who maximize their expected tenure in power defend their regime because they cannot survive regime change: to my best knowledge, there was never an autocrat who democratized and remained in office having won a competitive election. But the converse is not true: regimes stay while autocrats go. The question, then, is under what conditions people living in an autocracy consider that they would be better off under democracy than under an alternative autocrat. Most of the time, democ- 
racy is not in the realm of possibilities, so all people can do is to attach hopes to replacing one autocrat by another. Perhaps it is only when all of them fail does regime change appears on the political horizon.

\section{Puzzles}

\subsection{Is propaganda about facts or interpretations?}

All rulers - those selected in clean elections, those who hold this ceremony without putting their power at stake, and those who do not even bother to hold them - claim reasons they should be followed and people are willing to follow them if they believe these are good reasons. The Leader (an elected President, el Caudillo, il Duce, ein Führer), the Party, or the State defines who belongs to the collectivity and identifies the interests this collectivity has in common. The Leader offers to the people, in the words of Antonio Salazar, "a well-constituted order, rational as an expression of the nation organized, just in subordinating particular interests to the general, strong because of having as its basis the authority that cannot be rejected and should not be rejected...." (1934 speech, italics added; quoted in de Oliveira Marques 1998: 432). Coercion is rationalized as "the subordination of particular interests to the general": according to an eminent fascist leader, Alfredo Rocco, fascism was inspired by the idea of "liberty conditioned on the protection of general interests" (libertà condizionata dalla tutela degli interessi generali, quoted in Cassese 2011).

This is obviously "propaganda," but it is ideologically sobering to keep in mind that "Propaganda simply means the presentation of facts and arguments with a view to influencing people's actions or opinions in a definite direction. In itself therefore it does not carry any derogatory meaning and in particular it does not imply distortion of facts." (Schumpeter 2010: 411). ${ }^{8}$ After all, the very ideological foundation of representative institutions is the myth that people rule when they are ruled by others As Morgan (1988:13-14) observes, "Government requires make-believe ... Make believe that the king is divine, make believe that he can do no wrong or make believe that the voice of the people is the voice of God. Make believe that the people have a voice or make believe that the representatives of the people are the people." Propaganda is an instrument of rule in every regime. Its function is not only to prop up

\footnotetext{
${ }^{8}$ Mercier and Sperber (2011) argue that the main function of reasoning is not to pursue truth but to find arguments that persuade others: "Reasoning has evolved and persisted mainly because it makes human communication more effective and advantageous." Propaganda is then just a political extension of this inherent human predisposition.
} 
a regime against potential threats but to propagate shared beliefs, mobilize people toward shared goals, and coordinate actions, as in "United We Stand."

Is propaganda about facts or interpretations? Is it Bayesian persuasion or model persuasion? It must be the latter: otherwise what is the difference between propaganda and censorship? As Rozenas and Stukal (2019) observe with regard to Putin's Russia, "Bad news is not censored, but it is systematically blamed on external factors..." But it does not even have to be "rational persuasion" at all. In post-war communist Poland, the country was plastered with posters showing a poor peasant woman standing next to a graph, always in red, showing how everything will get better in the future, and being told that her son would become an engineer. I think that this propaganda had some effect but I am not convinced it was rational persuasion. The woman had no choice but to work hard and suffer poverty, so the propaganda rationalized the sacrifice she was making. It may have affected her posture toward the regime but it did not modify her perception of reality or her actions. Putin produced on 12 July 2021 a document on Ukraine, distributed to all soldiers in the Russian army, in which he says at one point, "... the idea of Ukrainian people as a nation separate from the Russians started to form and gain ground among the Polish elite and a part of the Malorussian intelligentsia." Whether this or is not true is not the point: I read it as saying to the soldiers, "This is why one day you may be ordered to fight." Providing people with justifications of actions with regard to which they have no choice rationalizes the inevitable whether or not it persuades.

Propaganda must be a comprehensive framework which ties together the past, the present, and the future. It must be incessantly reiterated, providing a causal interpretation of all punctual events and making it costly for individuals to evaluate all of its claims. (See Horz 2017 on "exhaustion propaganda."). Here is something I do recognize as propaganda:

... all frames promote party ideology to construct a political big picture that links individual frames and bestows an overarching meaning upon them. The country's social and economic development and respective policies in times of transition are thereby embedded in a long-term perspective, encompassing both a historic dimension and a future vision. The reference to the party's historic mission to lead China into a promising socialist future and the emphasis on the CCP's commitment to social and economic development that benefits the people accentuate the elites' efforts to serve 
the common interest. (Bondes and Heep 2013: 324)

\subsection{Why censorship works?}

The autocratic justification for censorship is that it screens harmful or false information. For example, the Portuguese Constitution of 1933 specified (in Article 3) that "The censorship will have the aim ... to impede the perversion of public opinion as a social force and should be exercised to defend it from all the factors that disorient it from truth, justice, morality, good administration and common good...." A July 1946 decree of the Polish Communist government instituted censorship "to avoid misleading public opinion by information that does not correspond to reality" (quoted in Tokarz 2012). The welfare effects of censorship might not be always negative: think of newspaper titles which report that someone, one in millions, had negative side effects from vaccination against the Covid. Yet governments that can censor some information can use this power to censor all information that it inconvenient to them, false or true.

Censorship is an observable signal that the monopolistic communicators fear that people would coordinate on rival beliefs, that rulers are hiding something or seek to mislead the public. There is something incongruent about a regime claiming that it enjoys widespread support and visibly censoring messages saying that it does not. The immediate question is why censorship would be ever effective. If people would completely reject messages that have been screened by censorship, such messages would have no effect on beliefs. ${ }^{9}$ Snyder and Ballentine (1996:14-15), for example, thought that people in communist regimes discounted propaganda because it originated from a monopolistic source. Yet censorship is widely used and it seems to often work (Enikopolov and Petrova 2015).

Models of censorship assume that nature generates a stream of states of the world that may be favorable or not to the regime and the autocrat adopts a strategy of communicating these states of the world to the public. One reason censorship works may be that even if people would have discounted censored messages, they do not know what has been censored. Shadmehr and Bernhardt (2015) argue that when citizens do not receive information about some state of the world, they do not know whether there was nothing to report or that information bad for the regime was censored. ${ }^{10}$ Censorship works because people do not think

\footnotetext{
${ }^{9} \mathrm{I}$ am told that in Beijing the websites reporting polution count are shut down when polution is extreme.

${ }^{10}$ In the Shadmehr and Bernhardt (2015) equilibrium, the ruler never completely
} 
about information they do not see. ${ }^{11}$ In the extreme, there is one kind of information that is never disclosed, because it is most dangerous to the regime: information about divisions within the elite.

Censorship operates at the margins; it only sets the limits to what can be publicly communicated. Yet existence of limits does not preclude pluralism of opinions that remain within the limits and even of institutions by which citizens can communicate their preferences within these limits. The communist systems, fascist Italy, as well as contemporary China and Iran, have had complex institutional systems of popular representation, allowing some upward transmission of popular demands. The principle of "democratic centralism" means that once a decision is made at the top, it must be obeyed even by those who had argued against it, but it does not preclude public debates of some issues. This pluralism, even if limited, obfuscates the very fact that there are limits.

Authoritarianism is a system in which there is only one authority that can communicate in public. Yet even if preferences have been manipulated by propaganda and censorship, the claim that people would have held different preferences had they been exposed to a plurality of reasons is counterfactual, and counterfactuals are unverifiable by construction. Hence, while the presence of propaganda and censorship can make us skeptical about the "authenticity" of people's beliefs, it does not offer a test of whether people's preferences induced by such beliefs are caused by these mechanisms. ${ }^{12}$

\subsection{Public and private beliefs}

A Polish joke about a meeting of a local cell of the Communist Party: Comrade Secretary delivers a speech on the dangers of American imperialism. Then all the comrades in the room express their opinions. All, but Comrade Kowalski. It is late Friday night, everyone wants to go home, yet Comrade Kowalski remains silent. Finally, Comrade Secretary turns to Comrade Kowalski, "Comrade Kowalski, I delivered my speech, all the comrades expressed their opinions, and you, you say nothing. Don't you have an opinion?" To which Comrade Kowalski sheepishly replies, "Oh, Comrade Secretary, the opinion I do have it. But I do not know if agree with it." (Wedeen 1999 tells a similar story about officer M).

Comrade Kowalski did not believe that American imperialism is dan-

censors all bad news but ends up censoring more than it would have had he been able to commit to a scheme of information disclosure.

${ }^{11}$ I owe this formulation to Andrew Little (personal communication). For the experimental evidence for this assertion, see Enke (2020).

${ }^{12}$ See Chen and Yang (2019) for an experimental study designed to get at this question. 
gerous but he had the opinion that it is. What was his "belief"? He did not update having received a public signal from the Comrade Secretary, sticking with his prior. But he signaled publicly that he is willing to act as if he did update.

Comrade Secretary was not trying to change beliefs about American imperialism. He was just demonstrating to all the comrades in the room that their beliefs do not matter. His prudential advice was "Do not act on your beliefs. Believe whatever you want, but this is how you should act." Game theorists would reply that there is nothing mysterious in that people would act in ways not consistent with their beliefs if they fear sanctions. Yet does it mean that I still believe or does the impossibility of acting on my true beliefs affects them and I come to believe what I am told to believe? Or do I believe both at the same time? Preventive repression - repression intended to prevent anti-regime individuals from acting or even from communicating their sentiments in anonymous interactions - is insidious. Fear becomes a habit and when we act out of habit we do not rationalize every act. Some actions are not to be undertaken, some thoughts are not to be communicated: it becomes instinctive. Compliance may entail fear but this fear is so deeply internalized that it does not appear as a motor of actions, not even as a limitation of freedom.

The question can be posed in a different language. Before political science became a branch of economics, when it was dominated by social psychology, we spoke in the language of "attitudes," defined as "behavioral predispositions." What was the attitude of Comrade Kowalski?

In the end, the question is what we should expect to hear if we were to ask someone what they believe. Should we expect to hear "I believe $p$ but acting on this belief is futile or even dangerous?" or "I believe $q$ ?". All the comrades other than Comrade Kowalski in the Polish story and all the officers other than M in Wedeen's (1999) answered " $q$ " in public. But what would they have answered in private? Which beliefs do people reveal when they answer survey questions saying that they support the Chinese Communist Party or President Putin? This is a question to which neither external observers nor the rulers have an answer. As Sen observed already in 1973 (p. 258; italics added), "People may be induced by social codes of behaviour to act as if they have different preferences from what they really have." Wedeen (1999: 82; see also Wintrobe 1998) observes, "requiring citizens to act 'as if' leaves the regime in the predicament of having to evaluate popular sentiment through the prism of enforced public dissimulation." The regime does not know how contingent is the manifest support it receives. 


\subsection{Cognitive status of "beliefs"}

What does it mean to "believe"? Many years ago a friend and I were being hosted by the Dean of the Economics Department of the University of Habana. My friend asked the Dean what she teaches, to which her answer was "The Capital." "And do you believe that was Marx says in The Capital is true?," my friend continued. Her shock was betrayed by an uncomprehending blank gaze. Shrugging her shoulders, she replied "It is in the program, so I teach it." It is expected of me to do it, so I do it: no "beliefs" are entailed. Is it true that actions must be supported by "beliefs"?

Did the Cuban Dean act of fear or only conformity? In Wedeen's (1999: 81) view,

Although the power involved in compelling such performances may seem to be of a lesser order than the power to alter beliefs, people are nevertheless required to enact a prescribed, politically congenial self for public presentation. Symbolic practices of power interfere with people's political "subjectivities," with their sense of themselves as political persons. Moreover, people can learn to be comfortable with their involvement, to identify with it as though it were something natural and inevitable and, ultimately, so they maywith no external urging - come to treat any non-involvement as an abnormality, as arrogance, as an attack on themselves, as a form of dropping out of society.

In the cafeteria of the Central Committee of the Polish Communist Party, over lunch, everyone used the ritualized official language: "the working class," "class conflict," "Comrade Secretary." (Szlachcic 1990). In their world there were no "workers" but only "the working class." If asked, they could not even define what "the working class" is. But they actually saw the world in such terms. Were they pretending, conforming, or what? (On this question, see Kuran 1995.)

\subsection{Complicity or duplicity?}

We all know this story: "Driven by hunger, a fox tried to reach some grapes hanging high on the vine but was unable to, although he leaped with all his strength. As he went away, the fox remarked 'Oh, you aren't even ripe yet! I don't need any sour grapes.'."

How do I justify my complicity to myself? My choices are to act against the regime, undermining its stability, to do nothing, or to ac-

tively collaborate, contributing to its stability. The decision to support 
must be psychologically tormenting for someone who does not like the regime. Perhaps this is why Wedeen thinks that supporters must hide their motives from themselves: why they are complicit but not duplicitous. Wedeen (1999: 77) writes "Complicity is doubly degrading when people deny to themselves that they are behaving in complicit ways. Ideology is insidious because it allows people to hide their reasons for obedience from themselves." Active support for the regime is not an act of deliberate deception but of some kind of rationalization of their motives. This may well be true, but the psychological mechanism remains opaque. "Rationalization" is a mechanism that generates logical consistency between beliefs and actions but causality may still run from actions to beliefs (Satz and Ferejohn 1994). ${ }^{13}$ The empirical status of Freudian psychodynamics is doubtful these days but some defense mechanisms denial, displacement, repression, sublimation, or what not - are required if I am to successfully hide my true motives from myself.

Active collaboration is often rationalized by the belief that working from within to improve the regime is the only effective course of action, even when it involves heinous acts. ${ }^{14}$ When all resistance is futile, one can at least try to steer the regime towards one's values rather than remaining passive. Moreover, the material rewards for collaboration are often high. As a French TV series, Un Village Français, admirably depicts, both collaboration and resistance can driven by ideological commitments, by opportunistic motivations, but also by purely emotional, sometimes even sexual, impulses. In situations of conflict, what are reasons for some are rationalizations for others, and they are hard to distinguish.

Can the psychology of postures toward regimes be captured by expected utilities? Expected utility is the same when the reward from the successful outcome is very high (someone truly hates the regime and believes revolution would bring paradise) while the probability of success is miniscule and when the reward is low while the probability is high. If you agree with Sen $(1988,1991)$ that people value having a choice, these utilities cannot be the same. In Sen's (1988) classical example, I may starve because I am poor or because I decided to fast: the outcome is the same but the utility of this outcome is different. In his words (1988: 292; italics in the original), "Doing $x$ and choosing to do $x$ are,

\footnotetext{
${ }^{13}$ In Ernest Jones's classical definition, rationalization is "the inventing of a reason for an attitude or action the motive of which is not recognized." According to Festinger (1957), people invent such reasons to reconcile logical inconsistencies among beliefs or between beliefs and actions.

${ }^{14}$ Sofer's (2020) Man of My Time is an exceptionally painful account of such collaboration.
} 
in general, not equivalent." But even without relying on Sen, consider an ardent regime opponent who realizes that no one can do anything to bring the regime down. Living in a status quo which one finds odious and seeing no possibility that it could be changed one feels impotent, despondent, and perhaps angry. It is just psychologically implausible that someone who feels intensely but cannot do anything would value this state of the world equally to someone who cares less and sees a good chance that it would happen.

\subsection{Are some beliefs invalid as a criterion of repre- sentation?}

The fundamental assumption of liberal conceptions of representation is that the preferences to be represented are exogenous with regard to the relation of representation. The "will" of the people is a primitive, given before anyone does anything. Pitkin's (1967: 140) claim that "the represented must be somehow logically prior" leads her to reject the possibility that someone can be represented if the wills are affected in the process of representing. Her red line is "manipulation": "[Representation] is perfectly compatible with leadership and with action to meet new or emergency situations. It is incompatible, on the other hand, with manipulation or coercion of the public...." (1967: 233).

Pitkin's assumption is patently unrealistic. Representation is never a unidirectional relation in which people want something and the representatives do or do not implement it. It is a dynamic relation, a tatonnement, by which individuals adjust their preferences on the basis of beliefs induced by the representatives and the representatives make decisions that anticipate the reactions of the represented to their messages. As Schumpeter (2010: 215) had it, "The will of the people is the product and not the motive power of the political process." Moreover, all regimes use coercion to prevent actions harmful to the collectivity. Even Bentham (1988 [1776]) argued that the legislators should be promoting "social actions" at the cost of "self-regarding" ones. But this is nothing other than using coercion in defense of common interests, so it cannot serve to disqualify a relation as representative.

Endogeneity of preferences, even if they are shaped by manipulation, is not sufficient to disqualify a relation as representative. But this need not imply that all endogenous preferences are equally valid as the criterion of representation. Here is Bay (1958: 322): "If support for the regime is manufactured by way of a monopoly control over the media of mass communication, supplemented by severe coercion against oppositional elements ..., one must conclude that no amount of public support 
to the regime can prove that the people's genuine interests are not being exploited in the interest of the ruling few." Yet note that while Pitkin makes a normative claim, Bay makes an epistemic one: claims that a regime enjoys support are unverifiable when the streets are quiet. When people cannot object, absence of protests is uninformative: we cannot tell whether they do not protest because they believe that the government acts in their best interest or because they fear repression. The usefulness of the concept of representation is limited: when Paris is burning, we see that people do not accept the government as representative but when Beijing is quiet we cannot tell whether if it is.

\subsection{Is "support" information contingent or alterna- tives contingent?}

In models going back to Schelling (1973) and extending through global games, the calculus made by each individual monotonically depends on the proportion of other individuals opposed to the regime. The expected value of opposing the regime depends on the probability the regime would collapse, which is signaled by the size of the opposition. Such models make prima facie sense but they rely on the assumption that the size of the opposition is informative about the probability of the regime falling. The question is whether "support" for the regime is contingent on information or on perceived alternatives, whether people support because they believe that the regime is good or because they believe that there are no alternatives. In communist Poland most people opposed the regime but no one believed that communism could fall because the Soviet army would not allow it. ${ }^{15}$ Only when it became clear that the Soviets could not or would not intervene did numbers begin to matter.

As Sen (1993) pointed out, not choosing the same element from different choice sets is not logically inconsistent. What one chooses depends on the options one faces: "An imperative assumption underlying the definition of consistency is that the choice context must be the same when determining whether two or more acts of choice are contradictory" (Mahmoud 2017:5). ${ }^{16}$ People may not like the available options (Sen 1997: 745; think of Sophie's Choice), but one can choose only from the options that are available. Only when the survival of a regime becomes uncertain, the option to act against the regime becomes envisagable..

\footnotetext{
${ }^{15}$ For the despair at the futility of resistance, see Haffner's (2003) 1939 memoir, which was horribly mistitled in English as Defying Hitler, from the German original of Memoir of a German.

${ }^{16}$ At stake here is the axiom of independence of irrelevant alternatives, which says that anyone who prefers $z$ over $y$ in the choice set $(y, z)$ must also prefer it in the set $(y, z, x)$; the availability of the alternative $x$ is irrelevant.
} 
Moreover, how can people evaluate states of the world which they never experienced (Sen 1993)? People in democratic countries are told that autocracy is bad because it is repressive; autocrats tell people that democracy is bad because it is disorderly; and most people under both types of regimes believe what they are told. Would Mr. Smith from Iowa support the CCP if he lived in Guandong; would Ms. Zhou from Guandong be an ardent democrat if she lived in Iowa? I know no way to answer such questions: while quite a few people in post-communist regimes kept saying that life was better under communism, they were probably just bemoaning that they got old. The question whether democrats bring about democracy or democracy generates democrats has been studied but the evidence is scarce and hard to interpret (Maravall 1995: Chapter 5). All we know is that we should be distrustful of preferences endogenous to regimes, which unfortunately holds for democracy as well.

\section{In the end}

While this essay may seem highly critical, it is not intended to question the recent advances in our understanding of authoritarian regimes, incisively summarized by Gehlbach, Sonin, and Svolik (2016). This is just a friendly nudge to delve behind ideological and methodological assumptions that in my view limit our grasp of complex, some bewildering, realities of these regimes. My doubts are whether the models elucidate the puzzle of popular support for autocratic regimes. I fear that, driven by methodological fashions, several models focus on autocratic practices that have a minimal effect on the functioning and the survival of these regimes. I doubt that the conceptual apparatus of game-theoretic models that entail "beliefs" can cope with the obscure psychological processes that make people remain passive, actively collaborate, or actively oppose autocratic regimes. ${ }^{17} \mathrm{I}$ have a lifelong friend who, after consuming half liter of vodka, still exclaimed "The Party is always right." I could never understand him and I have not seen a model that would help me understand him.

Which of these doubts apply to democracies as well? What is "opinion" in "public opinion"? Is propaganda more prevalent under autocracy than under democracy? Is centralized political repression more dissuasive than fear of decentralized social opprobrium? Are actions based on beliefs or driven by a desire to seek safety in confirming group membership? Are the preferences people hold more stable when they are

\footnotetext{
${ }^{17}$ On the general difficulty of distringuishing beliefs driven by "directional motives" from those based on different priors, see Little (2022). On the importance of emotions, see Green and Robertson (2020).
} 
exposed to conflicting messages, as J.S. Mill (1859) believed? We do not know answers to these questions.

\section{References}

Acemoglu, Daron, and James Robinson. 2006. Economic Origins of Dictatorship and Democracy. Cambridge University Press, 2006.

Arendt, Hanna. 1954. "What is Authority?" In Between Past and Future. New York: Viking Press. Pages 91-141.

Bay, Christian. 1958. The Structure of Freedom. Palo Alto: Stanford University Press.

Casper, Brett Allen and Scott Tyson. 2014. "Popular Protest and Elite Coordination in a Coup d' 'Etat." Journal of Politics 76: 548-564.

Cassese, Sabino. 2011. Lo Stato fascista. Milano: il Mulino.

Chen, Yuyu and David Y. Yang. 2019. "The Impact of Media Censorship: 1984 or Brave New World?" American Economic Review 109: 2294-2332.

Chen, Te-Ping. 2020. Land of Big Numbers: Stories. New York: Scribner.

Chen, Jidong and Yiqing Xu. 2015. "Information manipulation and reform in authoritarian regimes." Political Science Research and Methods $x x: 1-16$.

Chu, Yun-han. 2011. "Sources of Regime Legitimacy and the Debate over the Chinese Model." Revised paper for the conference on "The Chinese Models of Development: Domestic and Global Aspects," Center for International Studies, University of Virginia, November 4-5.

Cox, G. W. 2008. "Authoritarian elections and leadership succession, 1975-2000." Unpublished paper, Department of Political Science, University of California, San Diego.

de Oliveira Marques, A.H. 1998. História de Portugal. Volume III: Das Revoluções Liberais aos Nossos Dias. Lisboa: Editorial Presença.

Edmond, Chris. 2013, "Information manipulation, coordination, and regime change." Review of Economic Studies 80: 1422-1458.

Enikopolov, Ruben, and Maria Petrova. 2015. "Media Capture: Empirical Evidence." Handbook of Media Economics 1: 687-700.

Enke, Benjamin. 2020. "What you see is all there is." Quarterly Journal of Economics 135: 1363-1398.

Festinger, Leon. 1957. A Theory of Cognitive Dissonance.

Frye, Timothy, Scott Gehlbach, Kyle L. Marquardt, and John Ora Reuter. 2015. "Is Putin's Popularity Real?" Available at SSRN: https://ssrn.com/abstract=269204 or http://dx.doi.org/10.2139/ssrn.2692049

Friedrich, Carl J. 1958. "Authority, Reason, and Discretion." In Carl J. Friedrich (ed.), Authority. Nomos I. Cambridge, MA: Harvard 
University Press. Pages 28-48.

Galperti, Simone. 2018. "Persuasion: The Art of Changing Worldviews." Working paper, Department of Economics, University of California at San Diego.

Geddes, B. 2009. "How autocrats defend themselves against armed rivals." Paper presented at the Annual Meeting of the American Political Science Association, Toronto, Ontario, Canada.

Gehlbach, Scott, Konstantin Sonin, and Milan Svolik. 2016. "Formal Models of Nondemocratic Politics." Annual Review of Political Science 19: $565-584$.

Gehlbach, Scott, Zhaotian Luo, Anton Shirikov, and Dmitriy Vorobyev. 2021. "A Model of Censorship and Propaganda." Working paper.

Gentzkow, Matthew and Emir Kamenica. 2017. "Competition in Persuasion." Review of Economic Studies 84: 300-322.

Getty, J. A. 1991. "State and society under Stalin: Constitutions and elections in the 1930s." Slavic Review 50: 18-35.

Goldman, Wendy Z. 2007. Terror and Democracy in the Age of Stalin: The Social Dynamics of Represssion. New York: Cambridge University Press.

Green, S. and G. Robertson. 2020. "Affect and Autocracy: Emotions and Atittudes in Russia after Crimea." Perspectives on Politics, first view: 1-15.

Guriev, Sergei and Daniel Treisman. 2015. "How Modern Dictators Survive: Cooptation, Censorship, Propaganda, and Repression." Unpublished paper.

Guriev, Sergei and Daniel Treisman. 2019. "Informational Autocrats." Journal of Economic Perspectives 33: 100-127.

Haffner, Sebastian. 2003 [1939]. Defying Hitler: A Memoir. New York: Picador.

Horz, Carlo M. 2017. Strategic and Psychological Foundations of Propaganda. Ph.D. Dissertation, Department of Politics, New York University.

Kamenica, Emir. 2018. "Bayesian persuasion and information design." Working paper, Department of Economics, University of Chicago.

Kamenica, Emir and Matthew Gentzkow. 2011. "Bayesian Persuasion." American Economic Review 101: 2590-2615.

Kuran, Timur. 1995. Private Truths, Public Lies The Social Consequences of Preference Falsification. Cambridge, MA.: Harvard University Press.

Little, Andrew T. 2012. "Elections, fraud, and election monitoring in the shadow of revolution." Quarterly Journal of Political Science 7: 249-283. 
Little, Andrew T. 2017. "Propaganda and Credulity." Games and Economic Behavior 102: 224-232.

Little, Andrew T. 2022. "Detecting Motivated Reasoning." OSF Preprints: https://osf.io/b8tvk/

Luo, Zhaotian and Arturas Rozenas. 2018. "Strategies of Election Rigging: Trade-offs, Determinants, and Consequences." Quarterly Journal of Political Science 13: 1-28.

Maravall, José María. 1995. Los resultados de la democracia. Madrid: Alianza Editorial.

Matovski, Aleksandar. 2018. "It's the Stability, Stupid! How the Quest to Restore Order After the Soviet Collapse Shaped Russian Popular Opinion." Comparative Politics

50: 347-390.

Mercier, Hugo and Dan Sperber. 2011. "Why do humans reason? Arguments for an argumentative theory." Behavioral and Brain Sciences 34: 57-74; discussion 74-111.

Mill, J. S. 1989 [1859]. On liberty and other writings. Cambridge: Cambridge University Press.

Morgan, Edmund S. 1988. Inventing the People: the Rise of Popular Sovereignty in England and America. New York: W.W. Norton.

Pepinsky, Thomas. 2017. "Life in authoritarian states in mostly boring and tolerable." Vox, January 9.

Pitkin, Hanna. 1967. The Concept of Representation. Berkeley: University of California Press.

Przeworski, Adam. 2015. "Acquiring the Habit of Changing Governments Through Elections." Comparative Political Studies 48: 101-129.

Rozenas, Arturas. 2016. "Office insecurity and electoral manipulation." Journal of Politics 78: 232-248.

Rozenas, Arturas. 2020. "A Theory of Demographically Targeted Repression." Journal of Conflict Resolution 64: 1254-1278.

Rozenas, Arturas and Denis Stukal. 2019. "How Autocrats Manipulate Economic News: Evidence from Russia's State-Controlled Television." Journal of Politics 81: 982-996.

Satz, Debra and John Ferejohn. 1994. "Rational Choice and Social Theory." The Journal of Philosophy 91: 71-87

Schelling, Thomas C. 1973. "Hockey helmets, concealed weapons, and daytlight savinfg: A study of binary choices with externalities." Journal of Conflict Resolution 17: 381-428.

Schumpeter, Joseph. 2010 [1942]. Capitalism, Socialism, and Democracy. London: Routledge.

Shadmehr, Mehdi and Dan Bernhardt. 2011. "Collective Action with Uncertain Payoffs: Coordination, Public Signals and Punishment 
Dilemmas." American Political Science Review 105: 829-851.

Shadmehr, Mehdi and Dan Bernhardt. 2015. "State Censorship." American Economic Journal: Microeconomics 7: 1-29

Sen, Amartya. 1973. "Behaviour and the Concept of Preference." Economica, New Series, 40: 241-259.

Sen, Amartya. 1993. "Internal Consistency of Choice." Econometrica 61: 495-521.

Sen, Amartya. 1997. "Maximization and the Act of Choice." Econometrica 65: 745-779.

Serge, Victor. 2004 [1949]. The Case of Comrade Tulayev. New York: NYRB Classics.

Snyder, Jack and Karen Ballentine. 1996. "Nationalism and the Marketplace of Ideas." International Security 21: 5-40.

Sofer, Dalia. 2020. Man of My Time. New York: Farrar, Strauss, and Giroud.

Szlachcic, Franciszek. 1990. Gorzki Smak Wtadzy. Warszawa: FAKT.

Tokarz, Tomasz. 2012. "Cisza w służbie propagandy w PRL." Kultura $i$ Historia. www.kulturaihistoria.umcs.lublin.pl/archives/3154

Walder, Andrew G. and Qinglian Lu. 2017. "The Dynamics of Collapse in an Authoritarian Regime: China in 1967." American Journal of Sociology 122: 1144-1182.

Wedeen, Lisa. 1999. Ambiguities of Domination. Chicago: University of Chicago Press.

Wintrobe, Ronald. 1998. The Political Economy of Dictatorship. New York: Cambridge University Press. 